\title{
Antibiotic Resistance of Arcobacter spp. Isolated from Sewage, Meat Shop and Fish Market Environment of Bareilly City
}

\author{
D. B. Harkal ${ }^{1}$, Gulzar Ahmad ${ }^{1}$, R. S. Rathore ${ }^{1}$, S. V. S. Malik ${ }^{1}$, D. B. Rawool ${ }^{1}$, \\ Z. B. Dubal ${ }^{1}$, D. K. Singh ${ }^{1}$, Kumar Deepak ${ }^{2}$ and Saini Mohini ${ }^{3}$
}
${ }^{1}$ Department of Veterinary Public Health, ${ }^{2}$ Department of Animal Biotechnology, ${ }^{3}$ Department of Animal Biochemistry, Indian Veterinary Research Institute, Izatnagar, Bareilly-243122, Uttar Pradesh, India

*Corresponding author

\begin{tabular}{|l|}
\hline K e y w o r d s \\
Sewage, Arcobacter \\
spp., MDR strains, \\
Public health, Meat
\end{tabular}

\section{A B S T R A C T}

Arcobacter genus is an emerging pathogen, with three main spp. are pathogenic $(A$. butzleri, A. skirrowii and A. cryaerophilus) in nature. In present study raw sewage water, chicken, mutton and fish market associated environmental samples were screened for presence of Arcobacter spp. from Bareilly city of India. Out of total 170 samples, 50 from sewage water, 40 each of meat shops (chicken, mutton, fish) associated environment such as swab samples from knife (10), chopper (10), wooden block (10) and utensils (10) from each meat shop respectively. 26/170 (15\%) samples were positive for Arcobacter spp. by multiplex PCR detection and culture positive samples were 18/170 (10.58\%). The 8/50 from sewage water, 8/40 from chicken shop, 4/40 mutton shop and 6/40 from fish market associated environment detected positive by m-PCR. Out of total 170 samples screened 18 were culture positive with isolation rate $6 / 50(12 \%)$ from sewage water, $5 / 40(12.5 \%)$ from chicken shop, $3 / 40(7.5 \%)$ from mutton shop, $4 / 40$ (10\%) from fish market associated environments. Out of 18 Culture positive samples Arcobacter butzleri was predominant spp. isolated, than A. skirrowii and A. cryaerophilus and mix infection. The 18 positive strains were selected for disk diffusion, tested against 12 different types of antibiotic discs. High antibiotic resistance were seen as in cephalothin (17/18), co-trimoxazle (16/18), ampicillin (14/18), Vancomycin (14/18), tetracycline (14/18), kanamycin (12/18), Azitromycin (11/18) and other antibiotics shows greater sensitivity to Arcobacter butzleri with resistance pattern as $0 / 18$ by nalidixic acid, Erytromycin (4/18), Ciprofloxacin (4/18), Gentamicin (5/18) and streptomycin (6/18). Multi drug resistance (MDR) was seen in this the study. Which may concerned to treatment failure in human and animal concerned to Arcobacter MDR strains. Sewage water may acts as reservoir of Arcobacter spp. as human, animal excreta are major part in and associated water. Most of the sewage water is recycled by municipal corporation. Hence water processing plant, purification methods must aware of probable public health risk related to sewage water. More cautions are recommended for personnel hygiene in processing, handling and awareness related to meat and meat products. The unnecessary use or misuse of antibiotics should be limited or avoided for public health safety. 


\section{Introduction}

Though extensive study is not done on the epidemiology of Arcobacter species. The fact that they have many times isolated from poultry carcasses, sick animals and related to inflammation of intestine in humans strongly suggests that Arcobacter species may be key human bacterial pathogens (Philips, 2001).

In transmission of these pathogen water acts major source (Rice et al., 1993), and enteritis and dysentery are associated with Arcobacter has been reported from drinking of contaminated water. Activated sludge and sewage water were reported for presence of Arcobacter spp. with varied range from $41 \%$ 80\% (Stampi et al., 1999) suggesting high implications for animal and human health.

Genus Arcobacter amongst most common bacterial genera $(35.72 \%)$ seen in municipal sewage water (Gosh et al., 2019). Arcobacter species are among the main bacterial pathogens associated with sewage water and well-known for pathogenic nature (Fresia et al., 2019). Among the studies done at Study in the United States at west water treatment plant, McLellan et al., (2010) reported Arcobacter at major proportion as compared to other bacteria confirmed by pyrosequencing. Miller and Raghavan (2017) reported the bacterial diversity in samples from west water processing plant and concluded that Arcobacter spp. contains MDR genes and are in greater percent in sewage microbiome of sewage. A study done by GhajuShrestha et al., (2019) observed that that occurrence rate, detection of virulent genes (pldA and ciaB) of Arcobacter spp. by targeting 16S rRNA gene and detection 75\% and $83 \%$ from effluent and influent plant respectively.

In recent year, the importance of Arcobacter has been increased due to potential emergent zoonotic enteric pathogen (Ho et al., 2006; Snelling et al., 2006). The Arcobacter belongs within the epsilon class of proteobacteria in an atypical group and is recognized for a wide variety of hosts and habitats (Debruyne et al., 2008; Wesley et al., 2010). Arcobacter species are the pathogenic group merely associated with peritonitis, endocarditis and bacteremia and have been isolated as well as detected from stool irrespective of whether diarrheic or non diarrheaic (Abdelbaqi et al., 2007; Ho et al., 2006; Jiang et al., 2010; Kopilovic et al., 2008; Kownhar et al., 2007; Lau et al., 2002; Samie et al., 2007; Woo et al., 2001; vandamme et al., 1992; Van Driessche et al., 2003).

Arcobacter spp. have been associated with udder inflammation, abortions and GI disorders in the animals and also isolated from asymptomatic animals too (Vandamme et al., 1992; Van Driesshe et al., 2003).

As per ICMSF 2002, Arcobacterbutzleri is important zoonotic pathogen and may cause a serious health hazard in the humans and prevalent species from genus Arcobacter (Cardoen et al., 2009).

Arcobacters were isolated from different types of seafood irrespective of their sources such as fish landing centres, fish markets and water (Rathlavath et al., 2017).

\section{Materials and Methods}

\section{Sample collection and processing}

\section{Sample size and sources}

A total 50 sewage liquid samples were collected from different sewage chokes and raw sewage pond in the Bareilly city. 120 samples were collected by the swabbing the sources as knife (10), chopper (10), wooden block (10) and utensils 10) each from retail 
chicken shop, retail mutton shop and retail fish market in Bareilly city.

\section{Sewage water}

50 Sewage samples were collected from different Sewage choke in Bareilly city; $25 \mathrm{ml}$ of sewage liquid samples were collected in pre-sterilized sample collection bottle.

Brought in bacterial zoonosis lab of division of Veterinary public health, IVRI, Bareilly and further processed by filtration using Mixed Cellulose Ester filters $(0.22-\mu \mathrm{m}$ pore size $47 \mathrm{~mm}$ diameter, Sartorius, Germany) and inoculated in CAT broth subjected to incubation in microaerobic condition for 24 hrs (Fisher et al., 2014, Newton et al., 2013; Atabay and Corry, 1998)

\section{Swab sampling}

Sampling of different sources (knife, chopper, wooden block and utensils)

Before sampling, the sterile swabs were kept in $10 \mathrm{~mL}$ sterile peptone water in suitable conditions. After the sampling of the area, the swabs were placed aseptically back into peptone water. Immediately after sampling, the tubes containing the swabs were immediately carried to the lab in a mobile incubator and maintained at $4^{0} \mathrm{C}$. When the samples arrived at the laboratory, each tube containing the swab was vortexed for $10 \mathrm{~s}$ to assure mixture of the sample and transferred to CAT broth and incubated at $37^{\circ} \mathrm{C}$ in microaerobic condition (Kim and Yim, 2017 with some modification)

After enrichment, loopfull of enriched broth was taken and selective plating was done on selective agar medium Arcobacter agar with CAT supplement (CAT agar) and plates were incubated at $28^{\circ} \mathrm{C}$ under aerobic condition for 48-72 hrs.
Conventional isolation method of Arcobacter spp.

\section{Morphology and biochemical}

Gram negative, comma or "S" shaped all samples gave positive result to catalase, oxidase, Nitrate reduction test, indoxyl acetate hydroxyl test, and showed negative result to urease test, Hippurate hydrolysis test and $\mathrm{H}_{2} \mathrm{~S}$ production on TSI. And shows growth at $25^{\circ} \mathrm{C}$ and $37^{\circ} \mathrm{C}$ and shows no growth at $42^{\circ} \mathrm{C}$.

Testing of samples for presence of Arcobacter spp.

\section{DNA extraction and PCR assay}

DNA was isolated by snap chill method (Heatlysis method) Approximately $1.5 \mathrm{ml}$ of the Arcobacter enriched broth was subjected to pellet formation by centrifugation for $5 \mathrm{~min}$ at $8000 \mathrm{rpm}$ and then $100 \mu \mathrm{l}$ volume of triple distilled water added in it.

After keeping for $5 \mathrm{~min}$ in boiling water bath this pelleted volume containing bacterial lysate was then transferred directly to ice. Following bacterial lysate centrifugation at $13000 \mathrm{rpm}$ for $5 \mathrm{~min}$, supernatant was used as a DNA template for PCR analysis. The concentration of DNA isolated was estimated spectrophotometrically (Nanodrop®, US). The purity of DNA was checked as ratio of $\mathrm{OD}_{260}$ and $\mathrm{OD}_{280}$.

\section{Multiplex PCR protocol}

m-PCR reaction mixture of $50 \mu \mathrm{l}$ reaction volume was made containing following component. $\mathrm{MgCl}_{2}(5 \mu \mathrm{l})$, dNTP 2mM $(2 \mu \mathrm{l})$, primers ARCO, BUTZ, CRY-I, CRY-2 with 50 pmol volume $(2 \mu \mathrm{l}$ each) and SKIR 25 pmol $(2 \mu 1)$, 10X PCR Dream Taq buffer (5 $\mu \mathrm{l})$, Taq Polymerase 5U $(2 \mu \mathrm{l})$, Nuclease free water $(22 \mu \mathrm{l})$ and DNA template $(4 \mu \mathrm{l})$ (Primer details Table 1) 


\section{Cyclic conditions}

Initial denaturation $\left(94^{0} \mathrm{C}\right.$ for $\left.5 \mathrm{~min}\right)$, Denaturation $\left(94^{\circ} \mathrm{C}\right.$ for $\left.30 \mathrm{sec}\right)$, Annealing $\left(52^{0} \mathrm{C}\right.$ for $\left.30 \mathrm{sec}\right)$, Extension $\left(72^{\circ} \mathrm{C}\right.$ for $\left.1 \mathrm{~min}\right)$ -30 cycles and final extension $\left(72^{\circ} \mathrm{C}\right.$ for 10 $\min )$. In $1.5 \%$ agarose gel, the electrophoresis was done and thereafter analyzed by Gel Doc (UV trans-illuminator)

Primers and protocol was used as per Houf et al., (2000) with some modification for optimization.

\section{Antibiogram}

CAMHA (cation adjusted Muller Hington Agar) used for disk diffusion. Antibiotic disk used in study are purchased from Hi-media laboratory, Bombay, India and BD Sensi-Disc. All isolates confirmed by PCR were subjected to disk diffusion method for antibiotic sensitivity for commonly used antibiotic as described by Bauer et al., (1996).

Positive test culture was inoculated onto CAMHA plates by using sterile cotton swabs, plates are allowed to dry $(10 \mathrm{~min})$ then antibiotic discs were place with help of sterile foreceps. Further subjected to incubation for $48 \mathrm{hrs}$ at $28^{\circ} \mathrm{C}$ in microaerophilic condition.

\section{Bacterial strain maintened in laboratory}

Reference strain of A. butzleri (LMG10828T) maintained in Bacterial Zoonosis Lab, VPH was used as control positive DNA, whereas different positive strain of C. coli, C. jejuni, Salmonella and E. coli, used for differentiating from Arcobacter spp.

\section{Microaerophilic Assembly}

Microaerophilic jar, funnel filled water (60 $\mathrm{ml}$ ), chemicals (0.6 gm sodium borohydrate, $0.6 \mathrm{gm}$ sodium bicarbonate, $0.6 \mathrm{gm}$ citric acid) and different ready to use gas packs. To maintain $5 \% \mathrm{O}_{2}, 10 \% \mathrm{CO}_{2}, 85 \% \mathrm{~N}_{2}$ gaseous environment for selective growth of Arcobacter spp.

\section{Results and Discussion}

Out of total 170 samples screened sewage samples 16\% (8/50) positive for Arcobacter out of 8 positive samples 6 were A. butzleri, one sample was a mixture of two strain $(A$. cryaerophilus and A. butzleri) and one sample was positive for $A$. cryaerophilus when detected by m-PCR.

Out of total 170 screened samples 26 were found positive for Arcobacter spp. with overall percentage $15.29 \%$ detected by multiplex PCR (Fig. 5). Out of total 26 samples positive by PCR among them only 18 samples were culture positive (Fig. 1 and 2) and subjected to antibiotic sensitivity assay by using Disc diffusion methodology (Table 3, Fig. 3 and 4).

26 samples were found positive out of total 170 screened samples of Arcobacter spp. with overall percentage $15.29 \%$ detected by multiplex PCR. Out of total 26 samples positive by PCR among them only 18 (10.58\%) samples were cultures positive and subjected to antibiotic sensitivity assay by using Disc diffusion methodology (Bauer et al., 1996). Arcobacter isolation rate was much lower by culture isolation and biochemical tests as compared to the detection by multiplex PCR amplification assay. These results imply the high accuracy of Arcobacter detection level by multiplex PCR over conventional culture method. In 2007, similar results were reported from waste water samples and chicken samples by Gonzalez and colleagues during the direct detection of Arcobacter by PCR and conventional culture method. The m-PCR assay which can detect the species of Arcobacter specifically and 
rapidly than conventional biochemical identification method from the contaminated wastewater samples and chicken samples (Fig. $5)$.

Out of total 170 samples screened 18 were culture positive with isolation rate 6/50 (12\%) from sewage water, $5 / 40$ (12.5\%) from chicken shop, $3 / 40$ (7.5\%) from mutton shop, $4 / 40$ (10\%) from fish market associated environments respectively. In this study $8 / 50$ (16\%) sewage water sample were detected positive by mPCR amongst these six were Arcobacter butzleri. one sample had mixed infection (A. cryaerophilus and A. butzleri) and one Arcobacter skirrowii strain. While only six samples were found culture positive of them five were Arcobacter butzleri and one was identified as Arcobacter skirrowii isolate. In present study the Arcobacter incidence observed in water samples associated with fish market utensil was similar to those reported by Rathlavath et al., (2017).

The 18 positive strains were selected and tested for antibiotic susceptibility by disk diffusion method and tested against 12 different types of antibiotic discs. High antibiotic resistance were reported in cephalothin (17/18), co-trimoxazle (16/18), ampicillin (14/18), Vancomycin (14/18), tetracycline (14/18), kanamycin (12/18), Azitromycin (11/18) and other antibiotics shows greater sensitivity to Arcobacter butzleri with resistance pattern as $0 / 18$ by nalidixic acid, Erytromycin (4/18), Ciprofloxacin (4/18), Gentamicin (5/18) and streptomycin (6/18) respectively.

Antibiotic susceptibility pattern of Arcobacter spp. isolates from sewage water and meat shops (chicken, mutton and fish) associated environment such as swab samples from knife, chopper, wooden block and utensils from each meat shop and seafood market were also done (Table 3).

Resistance spectrum of Arcobacter spp. for 12 antibiotics tested in present study descending order was seen for cephalothin, co-trimoxazol, ampicillin, vancomycin, tetracycline, kanamycin, azithromycin, streptomycin, gentamicin, ciprofloxacin, erythromycin and nalidixic acid (Table 3 ).

Table.1 Details of primers used in present study

\begin{tabular}{|r|c|c|r|c|c|}
\hline $\begin{array}{l}\text { Sr. } \\
\text { no. }\end{array}$ & Primer & Gene & Primer sequence (5'-3') & Position & $\begin{array}{c}\text { Product } \\
\text { size }\end{array}$ \\
\hline $\mathbf{1}$ & BUTZ (Forword) & $16 \mathrm{~S}$ rRNA & $\begin{array}{r}\text { CCTGGACTTGACATAGTAAGAAT } \\
\text { GA }\end{array}$ & $959-983$ & $401 \mathrm{bp}$ \\
\hline $\mathbf{2}$ & ARCO (Reverse) & $16 \mathrm{~S}$ rRNA & CGTATTCACCGTAGCATAGC & $1357-1338$ & \\
\hline $\mathbf{3}$ & SKIR (Forword) & $16 \mathrm{~S}$ rRNA & GGCGATTTACTGGAACACA & $705-723$ & $641 \mathrm{bp}$ \\
\hline $\mathbf{4}$ & ARCO (Reverse) & $16 \mathrm{~S}$ rRNA & CGTATTCACCGTAGCATAGC & $1357-1338$ & \\
\hline $\mathbf{5}$ & CRY-I (Forword) & $23 \mathrm{~S}$ rRNA & TGCTGGAGCGGATAGAAGTA & $105-124$ & $257 \mathrm{bp}$ \\
\hline $\mathbf{6}$ & CRY-2 (Reverse) & $23 \mathrm{~S}$ rRNA & AACAACCTACGTCCTTCGAC & $359-340$ & \\
\hline
\end{tabular}


Table.2 Distribution of Arcobacter spp. in various samples isolated from sewage water, chicken, mutton and fish market associated environment of Bareilly city

\begin{tabular}{|c|c|c|c|c|c|c|}
\hline $\begin{array}{l}\text { Sr } \\
\text { no. }\end{array}$ & Source & $\begin{array}{l}\text { Arcobacter } \\
\text { spp. }\end{array}$ & $\begin{array}{c}\text { Arcobacter } \\
\text { butzleri }\end{array}$ & $\begin{array}{l}\text { Arcobacter } \\
\text { cryaerophilus }\end{array}$ & $\begin{array}{c}\text { Arcobacter } \\
\text { skirrowii }\end{array}$ & $\begin{array}{c}\text { Mix of } A . \text { butzleri and } \\
\text { A. cryaerophilus }\end{array}$ \\
\hline 1 & Sewage (50) & 8 & 6 & 0 & 1 & 1 \\
\hline 2 & $\begin{array}{l}\text { Sample from chicken } \\
\text { shop } \\
\text { i) knife (10) } \\
\text { ii) chopper (10) } \\
\text { iii) wodden block (10) } \\
\text { iv) utensils (10) }\end{array}$ & 8 & $\begin{array}{l}1 \\
2 \\
3 \\
2\end{array}$ & $\begin{array}{l}0 \\
0 \\
0 \\
0\end{array}$ & $\begin{array}{l}0 \\
0 \\
0 \\
0\end{array}$ & $\begin{array}{l}0 \\
0 \\
0 \\
0\end{array}$ \\
\hline 3 & $\begin{array}{l}\text { Samples from mutton } \\
\text { shop } \\
\text { i) knife (10) } \\
\text { ii) chopper (10) } \\
\text { iii) wodden block (10) } \\
\text { iv) utensils (10) }\end{array}$ & 4 & $\begin{array}{l}0 \\
1 \\
2 \\
1\end{array}$ & $\begin{array}{l}0 \\
0 \\
0 \\
0\end{array}$ & $\begin{array}{l}0 \\
0 \\
0 \\
0\end{array}$ & $\begin{array}{l}0 \\
0 \\
0 \\
0\end{array}$ \\
\hline 4 & $\begin{array}{l}\text { Samples from fish } \\
\text { markets } \\
\text { I) knife (10) } \\
\text { ii) chopper (10) } \\
\text { iii) wooden block (10) } \\
\text { iv) utensils (10) }\end{array}$ & 6 & $\begin{array}{l}0 \\
1 \\
2 \\
3\end{array}$ & $\begin{array}{l}0 \\
0 \\
0 \\
0\end{array}$ & $\begin{array}{l}0 \\
0 \\
0 \\
0\end{array}$ & $\begin{array}{l}0 \\
0 \\
0 \\
0\end{array}$ \\
\hline
\end{tabular}

Fig.1 Gram's staining of Arcobacter spp.

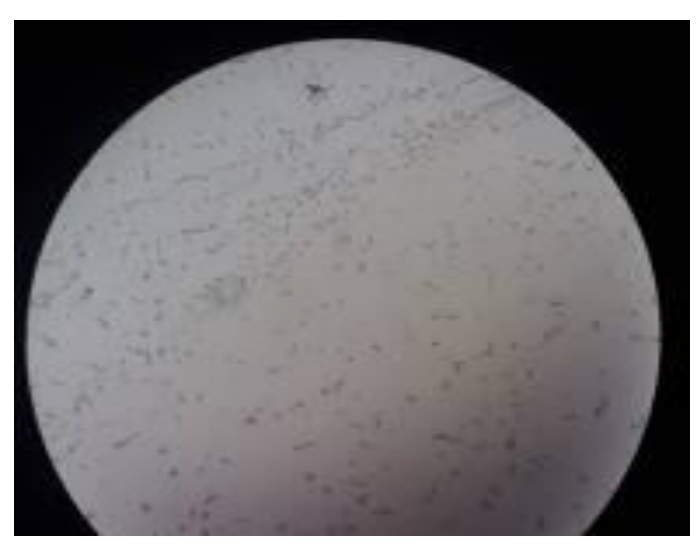


Table.3 Antibiotic susceptibility pattern of 18 selected strains of Arcobacter spp.

\begin{tabular}{|c|c|c|c|c|c|c|c|c|c|c|c|c|c|c|c|}
\hline \multirow{4}{*}{$\begin{array}{l}\text { Sr } \\
\text { No. }\end{array}$} & \multirow{4}{*}{$\begin{array}{l}\text { Types of } \\
\text { Antibiotics }\end{array}$} & \multirow{4}{*}{$\begin{array}{c}\text { Concentration } \\
\text { (mcg/disc) }\end{array}$} & \multirow{4}{*}{$\begin{array}{c}\text { Sewage } \\
(6)\end{array}$} & \multirow{2}{*}{\multicolumn{4}{|c|}{ Chicken shop }} & \multicolumn{4}{|c|}{ Mutton shop } & \multicolumn{4}{|c|}{ Fish market } \\
\hline & & & & & & & & \multicolumn{4}{|c|}{ (3) } & \multicolumn{4}{|c|}{ (4) } \\
\hline & & & & \multirow[t]{2}{*}{$\mathrm{i}$} & ii & iii & iv & \multirow[t]{2}{*}{$\mathrm{i}$} & ii & iii & iv & I & ii & iii & iv \\
\hline & & & & & $(-1)$ & $(-2)$ & $(-2)$ & & $(-1)$ & $(-1)$ & $(-1)$ & & $(-1)$ & $(-2)$ & $(-1)$ \\
\hline 1 & Tetracycline & $30 \mathrm{mcg} / \mathrm{disc}$ & $(4+)(2-)$ & $*$ & + & ++ & ++ & $*$ & + & - & - & $*$ & + & ++ & + \\
\hline 2 & Gentamicin & $10 \mathrm{mcg} / \mathrm{disc}$ & $(1+)(5-)$ & $*$ & - & -+ & -- & $*$ & - & - & + & $*$ & - & ++ & - \\
\hline 3 & Vancomycin & $5 \mathrm{mcg} / \mathrm{disc}$ & $(5+)(1-)$ & $*$ & + & -+ & ++ & $*$ & + & + & - & $*$ & - & ++ & + \\
\hline 4 & Ampicillin & $10 \mathrm{mcg} / \mathrm{disc}$ & $(5+)(1-)$ & $*$ & + & ++ & -- & $*$ & - & + & + & $*$ & + & ++ & + \\
\hline 5 & Erytromycin & $15 \mathrm{mcg} / \mathrm{disc}$ & $(2+)(4-)$ & $*$ & - & - - & ++ & $*$ & - & - & - & $*$ & - & - & - \\
\hline 6 & Nalidixic acid & $30 \mathrm{mcg} / \mathrm{disc}$ & $(6-)$ & $*$ & - & - - & -- & $*$ & - & - & - & $*$ & - & -- & - \\
\hline 7 & Azitromycin & $15 \mathrm{mcg} / \mathrm{disc}$ & $(4+)(2-)$ & $*$ & - & +- & ++ & $*$ & + & - & + & $*$ & + & +- & - \\
\hline 8 & Kanamycin & $30 \mathrm{mcg} / \mathrm{disc}$ & $(4+)(2-)$ & $*$ & - & ++ & +- & $*$ & + & + & - & $*$ & - & ++ & + \\
\hline 9 & Cephalothin & $30 \mathrm{mcg} / \mathrm{disc}$ & $(6+)$ & $*$ & + & ++ & ++ & $*$ & + & + & - & $*$ & + & ++ & + \\
\hline 10 & Streptomycin & $10 \mathrm{mcg} / \mathrm{disc}$ & $(3+)(3-)$ & $*$ & - & - - & -- & * & + & - & - & * & - & +- & + \\
\hline 11 & Ciprofloxacin & $5 \mathrm{mcg} / \mathrm{disc}$ & $(1+)(5-)$ & $*$ & - & - - & -+ & $*$ & - & + & - & $*$ & - & -+ & - \\
\hline 12 & Co-trimoxazle & $25 \mathrm{mcg} / \mathrm{disc}$ & $(5+)(1-)$ & $*$ & + & ++ & ++ & * & + & - & + & $*$ & + & ++ & + \\
\hline
\end{tabular}

Remark: i- sample from knife, ii-sample from chopper, iii-sample from wooden block, iv- sample from utensils

Sign + : Antibiotic Resistant isolate; - : Antibiotic Sensitive isolate * : culture negative /not tested

Fig.2 Typical Arcobacter colony on CAT agar

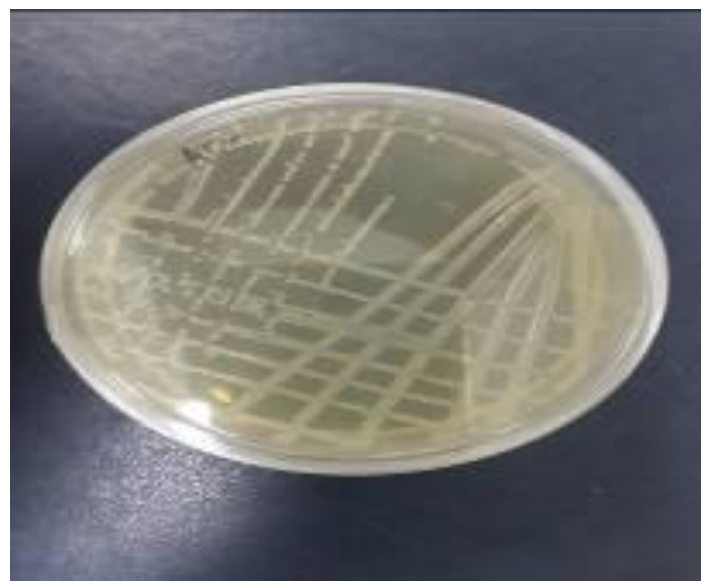


Fig.3 Antibiotic Assay (Disc diffusion) showing resistance and sensitivity

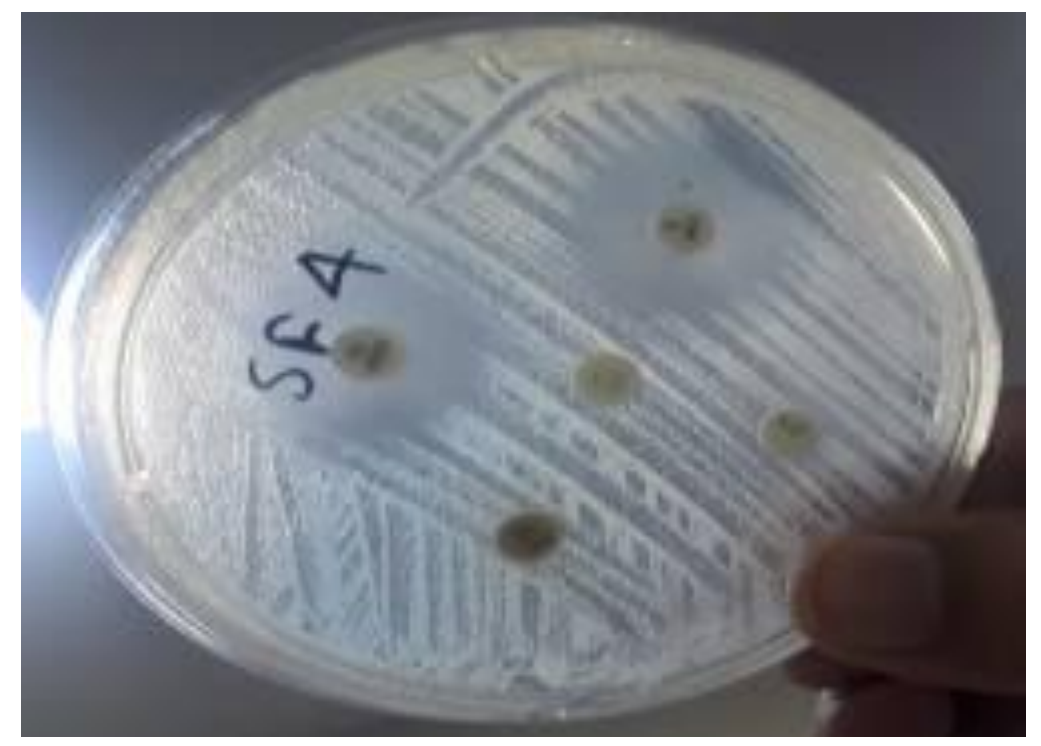

Fig.4 Disc diffusion showing sensitivity to Arcobacter

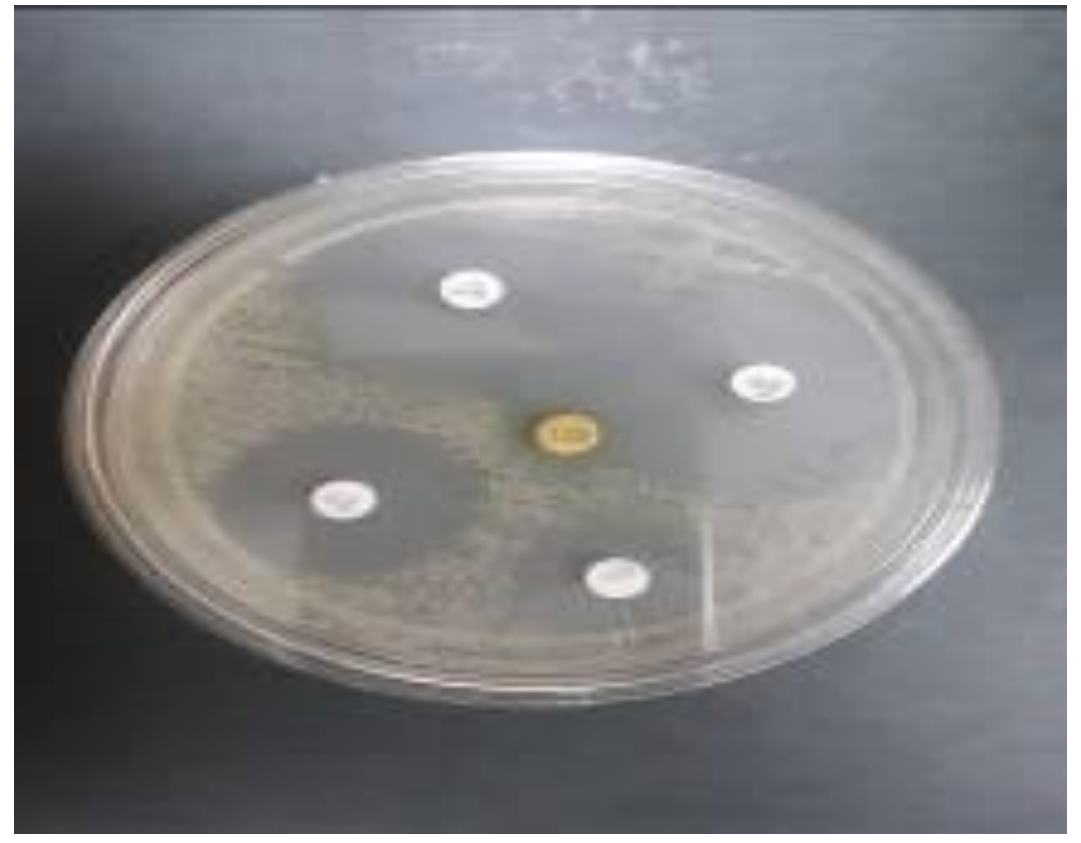


Fig.5 Identification of Arcobacter spp. amplified from enriched culture broth by multiples PCR
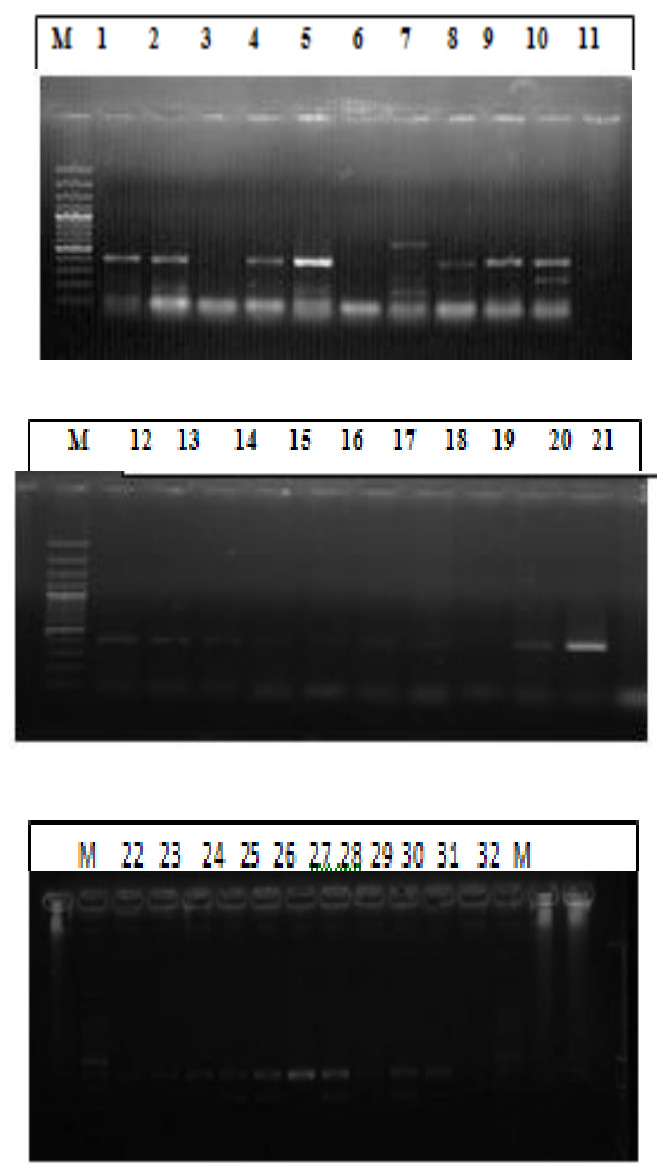

Lane M

Lane 1, 2, 4, 5, 8, 9

Lane 3, 6, 11, 19, 32

Lane 7

Lane $10,25,26,28,30$

Lane 12-18, 20, 21,22

Lane 22-24,27,29,31
100 bp ladder

Arcobacter butzleri (401 bp)

Negative samples

Arcobacter skirrowii (641 bp)

Mix (A. butzleri $401 \mathrm{bp}$ and A. cryaerophilus 257 bp)

Arcobacter butzleri (401 bp)

Arcobacter butzleri (401 bp)
Due to the major contribution of fecal contamination in sewage water, we also agreeing the hypothesis that these samples were more rich and diverse in antibiotic resistance mechanisms and can generate the MDR bacterial strains as compared to strains detected from municipal water samples as observed by Fresia et al., (2019).

\section{References}

Abdelbaqi, K., et al., 2007. Development of a real-time fluorescence resonance energy transfer PCR to detect Arcobacter species. J. Clin. Microbiol. 45: 30153021.

Atabay, H.I., Corry, J.E. and On, S.L., 1998.Diversity and prevalence of Arcobacter spp. in broiler chickens. Journal of Applied Microbiology, 84(6), pp. 1007-1016.

Atabay, H.I., Corry, J.E., 1998. Evaluation of a new Arcobacter enrichment medium and comparison with two media developed for enrichment of Campylobacter spp. International Journal of food 
microbiology, 41(1), pp.53-58.

Bauer, A. W., Kigby, W.M.M., Sherris, J. C. and Truck, M. (1996). Antibiotic susceptibility testing by a standardized disc method. Am. J. Clin. Pathol., 45, 493-496.

Cardoen, S., et al., 2009. Evidence-based semiquantitative methodology for prioritization of foodborne zoonoses. Foodborne Pathog. Dis. 6: 1083-1096.

Debruyne, L., D. Gevers, and P. Vandamme. 2008. Taxonomy of the family Campylobactereaceae. p. 3-25. In I. Nachamkin, C. Szymanski, and M. Blaser (ed.), Campylobacter, 3rd ed. ASM Press, Washington, DC.

Fisher, J. C., Levican, A., Figueras, M.J. and McLellan, S.L., 2014. Population dynamics and ecology of Arcobacter in sewage. Frontiers in microbiology, 5, p.525.

Fresia, P., Antelo, V., Salazar, C., Giménez, M., D'Alessandro, B., Afshinnekoo, E., Mason, C., Gonnet, G.H. and Iraola, G., 2019. Urban metagenomics uncover antibiotic resistance reservoirs in coastal beach and sewage waters. Microbiome, 7(1), p.35.

GhajuShrestha, R., Sherchan, S.P., Kitajima, M., Tanaka, Y., Gerba, C.P. and Haramoto, E. 2019. Reduction of Arcobacter at Two Conventional Wastewater Treatment Plants in Southern Arizona, USA. Pathogens, 8(4), p.175.

Ghosh, P., Kumar, M., Kapoor, R., Kumar, S.S., Singh, L., Vijay, V., Kumar Vijay, V., Kumar, V., Shekhar Thakur, I. 2019. Enhanced biogas production from municipal solid waste via co-digestion with sewage sludge and metabolic pathway analysis, Bioresource Technology 296, p. 122275.

Gonzalez, A., Botella, S., Montes, R.M., Moreno, Y. and Ferrus, M.A., 2007. Direct detection and identification of Arcobacter species by multiplex PCR in chicken and wastewater samples from Spain. Journal of food protection, 70(2), pp.341-347.

Ho, H. T., L. J. Lipman, and W. Gaastra. 2006. Arcobacter, what is known and unknown about a potential foodborne zoonotic agent! Vet. Microbiol. 115:113.

Houf K., Tutenel A., De Zutter, L., Van Hoof, J. and Vandamme, P. (2000). Development of a multiplex PCR assay for the simultanieous detection and identification of Arcobacter butzleri, Arcobacter cryaerophilus and Arcobacter skirrowii. FEMS Immunol Med Microbiol., 49(3), 337-345.

ICMSF. 2002. Microorganisms in foods. 7. Microbiological testing in food safety management. International Commission on Microbiological Specifications for Foods. Kluwer Academic/Plenum, New York, NY.

Jiang, Z. D., et al., 2010. Microbial etiology of travelers' diarrhea in Mexico, Guatemala and India importance of enterotoxigenic Bacteroides fragilis and Arcobacter species. J. Clin. Microbiol. 48:1417-1419.

Kopilovic, B., V. Ucakar, N. Koren, M. Krek, and A. Kraigher. 2008. Waterborne outbreak of acute gastroenteritis in a coastal area in Slovenia in June and July 2008. Eurosurveillance 13:1-3.

Kownhar, H., E. M. Shankar, R. Rajan, A. Vengatesan, and U. A. Rao. 2007. Prevalence of Campylobacter jejuni and enteric bacterial pathogens among hospitalized HIV infected versus nonHIV infected patients with diarrhoea in southern India. Scand. J. Infect. Dis. 39:862-866.

Lau, S. K., P. C. Woo, J. L. Teng, K. W. Leung, and K. Y. Yuen. 2002. Identification by $16 \mathrm{~S}$ ribosomal RNA gene sequencing of Arcobacter butzleri bacteraemia in a patient with acute gangrenous appendicitis. Mol. Pathol. 55:182-185.

McLellan, S.L., Huse, S.M., Mueller-Spitz, S.R., Andreishcheva, E.N., Sogin, M.L. Diversity and population structure of sewage-derived microorganisms in 
wastewater treatment plant influent. Environ. Microbiol. 2010, 12, 378-392.

Millar, J.A., Raghavan, R. Accumulation and expression of multiple antibiotic resistance genes in Arcobacter cryaerophilus that thrives in sewage. Peer J. 2017, 5, e3269.

Musmanno, R. A., M. Russi, H. Lior, and N. Figura.1997. In vitro virulence factors of Arcobacter butzleri strains isolated from superficial water samples. Microbiologica, 20: 63-68.

Newton, R.J., Bootsma, M.J., Morrison, H. G., Sogin, M. L. and McLellan, S.L., 2013. A microbial signature approach to identify fecal pollution in the waters off an unbanized coast of Lake Michigan. Microbial ecology, 65(4), 1011-1023.

Phillips, C. A. 2001. Arcobacters as emerging human foodborne pathogens. Food Control 12:1-6.

Rathlavath, S., Kumar, S. and Nayak, B.B., 2017. Comparative isolation and genetic diversity of Arcobacter sp. from fish and the coastal environment. Letters in applied microbiology, 65(1), pp. 42-49.

Rice, E. W., M. R. Rodgers, I. V. Wesley, C. H. Johnson, and S. A. Tanner. 1999. Isolation of Arcobacter butzleri from ground water. Lett. Appl. Microbiol. 28:31-35.

Samie, A., C. L. Obi, L. J. Barrett, S. M. Powell, and R. L. Guerrant. 2007. Prevalence of Campylobacter species, Helicobacter pylori and Arcobacter species in stool samples from the Venda region, Limpopo, South Africa: studies using molecular diagnostic methods. J. Infect. 54: 558-566.

Snelling, W. J., M. Matsuda, J. E. Moore, and J. S. Dooley. 2006. Under the microscope: Arcobacter. Lett. Appl. Microbiol. 42:714.

Stampi, S., De Luca, G., Varoli, O., Zanetti, F. Occurrence, removal and seasonal variation of thermophilic Campylobacters and Arcobacter in sewage sludge. Zentralblattfür Hygiene und Umweltmedizin 1999, 202, 19-27.

Van Driessche, E., K. Houf, J. van Hoof, L. De Zutter, and P. Vandamme. 2003. Isolation of Arcobacter species from animal feces. FEMS Microbiol.Lett. 229:243-248.

Vandamme, P., et al., 1992. Polyphasic taxonomic study of the emended genus Arcobacter with Arcobacter butzleri comb. nov. and Arcobacter skirrowii sp. nov., an aerotolerant bacterium isolated from veterinary specimens. Int. J. Syst. Bacteriol. 42: 344-356.

Wesley, I. V., and Miller, G. W. 2010. Arcobacter: an opportunistic human food-borne pathogen? Pp. 185-211. In: W. M. Scheld, M. L. Grayson, and J. M. Hughes (ed.), Emerging infections 9. ASM Press, Washington, DC.

Woo, P. C., K. T. Chong, K. Leung, T. Que, and K. Yuen. 2001. Identification of Arcobacter cryaerophilus isolated from a traffic accident victim with bacteremia by $16 \mathrm{~S}$ ribosomal RNA gene sequencing. Diagn. Microbiol. Infect. Dis. 40:125-127.

\section{How to cite this article:}

Harkal, D. B., Gulzar Ahmad, R. S. Rathore, S. V. S. Malik, D. B. Rawool, Z. B. Dubal, D. K. Singh, Kumar Deepak and Saini Mohini. 2019. Antibiotic Resistance of Arcobacter spp. Isolated from Sewage, Meat Shop and Fish Market Environment of Bareilly City. Int.J.Curr.Microbiol.App.Sci. 8(12): 1987-1997. doi: https://doi.org/10.20546/ijcmas.2019.812.237 